ARTICLE

\title{
A role for subducted albite in the water cycle and alkalinity of subduction fluids
}

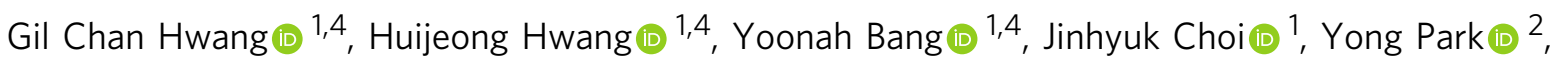
Tae-Yeol Jeon ${ }^{3}$, Boknam Chae ${ }^{3}$, Haemyeong Jung $\mathbb{C}^{2} \&$ Yongjae Lee (i) ${ }^{1 凶}$

Albite is one of the major constituents in the crust. We report here that albite, when subjected to hydrous cold subduction conditions, undergoes hitherto unknown breakdown into hydrated smectite, moganite, and corundum, above $2.9 \mathrm{GPa}$ and $290^{\circ} \mathrm{C}$ or about $90 \mathrm{~km}$ depth conditions, followed by subsequent breakdown of smectite into jadeite above $4.3 \mathrm{GPa}$ and $435{ }^{\circ} \mathrm{C}$ or near $135 \mathrm{~km}$ depth. Upon the hydration into smectite, the fluid volume of the system decreases by $\sim 14 \%$, whereas it increases by $\sim 8 \%$ upon its dehydration into jadeite. Both the hydration and dehydration depths are correlated to increases in seismicity by $93 \%$ and $104 \%$, respectively, along the South Mariana trench over the past 5 years. Moreover, the formation of smectite is accompanied by the release of $\mathrm{OH}^{-}$species, which would explain the formation of moganite and expected alkalinity of the subducting fluid. Thus, we shed new insights into the mechanism of water transport and related geochemical and geophysical activities in the contemporary global subduction system.

\footnotetext{
${ }^{1}$ Department of Earth System Sciences, Yonsei University, Seoul, Korea. ${ }^{2}$ School of Earth and Environmental Sciences, Seoul National University, Seoul, Korea. ${ }^{3}$ Beamline Science Division, Pohang Accelerator Laboratory, Pohang, Korea. ${ }^{4}$ These authors contributed equally: Gil Chan Hwang, Huijeong

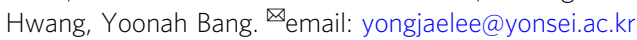


$\mathrm{S}$ ubduction zones are important geochemical and geophysical interfaces as oceanic plates sink deep into the Earth transporting and cycling rocks and volatile components, such as water and carbon dioxide, between the surface and the mantle ${ }^{1-4}$. Understanding the mineral-water interaction along subduction zone conditions is therefore critical as it is related to metamorphism, magma generation, and earthquake triggering along the subducting plate $3,5-11$ and in the overlying mantle wedge ${ }^{2}$. Alkali feldspars are important components of the subducting oceanic plate that have been used to model the generation of magma and the evolution of lithospheric mantle composition ${ }^{12-14}$.

Amongst alkali feldspars, albite $\left[\mathrm{NaAlSi}_{3} \mathrm{O}_{8}\right]$ accounts $\sim 16 \%$ and $\sim 10 \%$ in volume in basalt and gabbro in the oceanic crust, respectively ${ }^{8}$. Generally, anhydrous albite has been reported to transform to jadeite and quartz under high temperature-pressure conditions in the range of $1-3 \mathrm{GPa}$ and $200-1000^{\circ} \mathrm{C}^{7,15,16}$. On the other hand, Shen and Keppler reported complete miscibility between silicate melts and hydrous fluids in the near surface conditions from visual observations in the albite $-\mathrm{H}_{2} \mathrm{O}$ system ${ }^{13}$.

A series of mineral transformations have been established along diverse subduction geotherms in relation to the observed metamorphic facies ${ }^{17,18}$. Dehydration and breakdown of hydrous minerals down to ca. $240 \mathrm{~km}$ depth are believed to impact the chemical and physical properties of subducting rocks ${ }^{9,19}$. It is uncertain, however, how mineral transformation is related to the chemistry of subduction fluids, specially its mildly alkaline nature. Galvez et al. reported that the degree of $\Delta \mathrm{pH}$ may be caused by intramantle differentiation or infiltration of fluids enriched in alkali components extracted from the subducted crust $^{3}$. In this study, we report the first experimental evidence of alkaline fluid generation from the breakdown reaction in the anhydrous albite-water system under cold subducting slab conditions down to about $170 \mathrm{~km}$ in depth. We found that starting at $2.9 \mathrm{GPa}$ and $290^{\circ} \mathrm{C}$ or about 90 $\mathrm{km}$ depth along cold subducting slab, albite breaks down to form a mixture of smectite, moganite, and corundum, which releases $\mathrm{OH}^{-}$ species in a 5:4 molar ratio. We suspect that this would impact the $\mathrm{pH}$ of subducting fluid by as much as $\Delta \mathrm{pH}$ of $2.2-2.5$, which is extrapolated from the calculation of $\Delta \mathrm{pH}$ of solutions in equilibrium with subducting basaltic slab ${ }^{3}$.

In this work, we performed in situ high-pressure and -temperature synchrotron X-ray diffraction (XRD) experiments under three different sample conditions using a resistive-heating diamond anvil cell (DAC): (1) up to $5.4 \mathrm{GPa}$ and $570{ }^{\circ} \mathrm{C}$ (cold subduction slab and wet condition, down to ca. $170 \mathrm{~km}$ depth); (2) up to $3.2 \mathrm{GPa}$ and $530{ }^{\circ} \mathrm{C}$ (warm subduction slab and wet condition, down to ca. $100 \mathrm{~km}$ depth); (3) up to $4.7 \mathrm{GPa}$ and $505^{\circ} \mathrm{C}$ (cold subduction slab and dry condition, down to ca. $145 \mathrm{~km}$ depth). In wet condition experiments, powdered samples of albite were immersed in water in a ca. 1:1 by volume ratio as a pressure-transmitting medium (PTM). In dry condition experiment, no PTM was added to anhydrous albite.

\section{Results}

In situ high-pressure and high-temperature studies using a DAC. Upon increase in pressure and temperature in wet and cold subduction conditions following the geothermal gradients along the South Mariana trench ${ }^{20}$, we observed that albite breaks down to hydrated Na-smectite (beidellite), moganite, and corundum above $2.9 \mathrm{GPa}$ and $290^{\circ} \mathrm{C}$ or about $90 \mathrm{~km}$ depth, as below (Fig. 1 and Supplementary Fig. 1).

$$
\begin{aligned}
5 \mathrm{NaAlSi}_{3} \mathrm{O}_{8}+4 \mathrm{H}_{2} \mathrm{O} \rightarrow & \mathrm{NaAl}_{2}\left(\mathrm{Si}_{3} \mathrm{Al}\right) \mathrm{O}_{10}(\mathrm{OH})_{2} \cdot \mathrm{H}_{2} \mathrm{O}+12 \mathrm{SiO}_{2} \\
& +\mathrm{Al}_{2} \mathrm{O}_{3}+4 \mathrm{Na}^{+}+4 \mathrm{OH}^{-} \\
\text {Albite } & 1 \mathrm{~W} \mathrm{Na}-\text { smectite (beidellite) Moganite Corundum }
\end{aligned}
$$

The appearance of the characteristic (001) diffraction peak at $d_{001} \sim 12 \AA$ indicates that the newly formed Na-smectite is

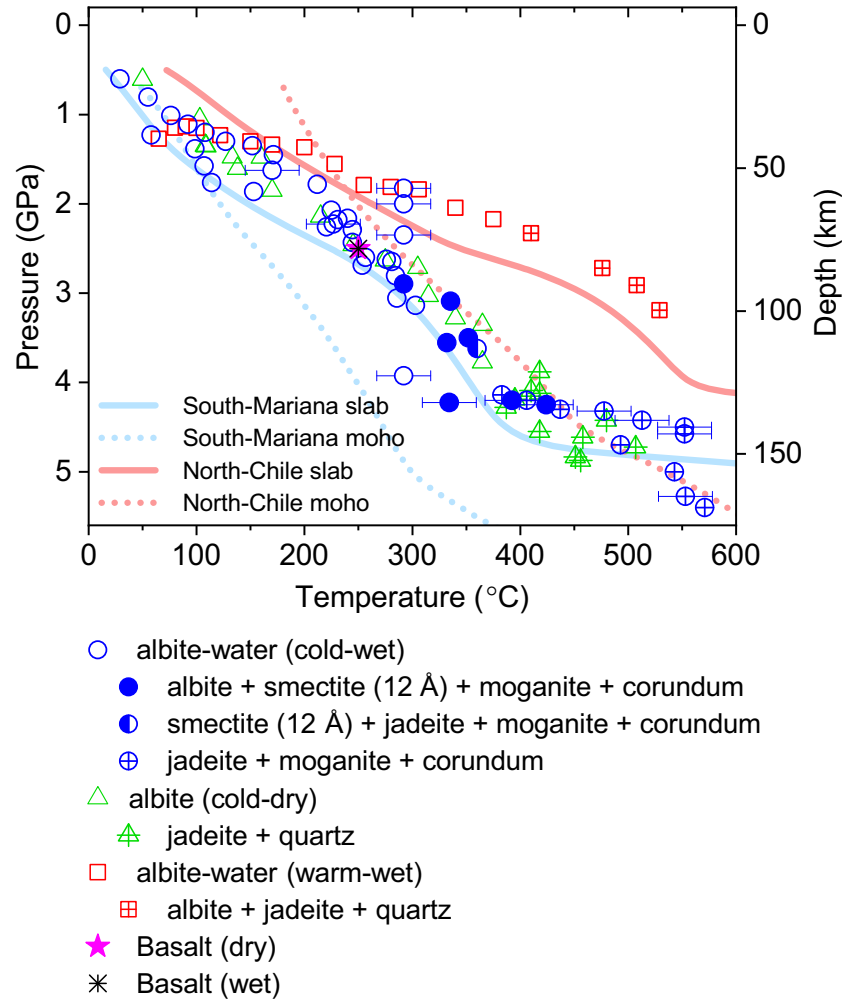

Fig. 1 Stability of albite along three different PT conditions. Thermal gradients of the Mariana (cold) and the North Chile (warm) slabs are shown in blue and red lines, respectively, following the W1300 model by Syracuse et al. ${ }^{20}$. Dotted lines are geotherms for $7 \mathrm{~km}$ beneath the respective slab surface. Horizontal error bars show the uncertainties in temperature.

hydrated with one layer of water with a total water content of ca. 9.0 wt.\% (Fig. 2a). In a smectite clay structure, it has been established that the interlayer is mono-hydrated (1W model) when $d_{001}$ is in the range between $11.8-12.9 \AA^{21,22}$. The observed transformation of albite along the hydrous cold subduction conditions thus reveal hitherto unknown breakdown reaction to form a hydrated clay mineral, which is quite different from the established breakdown scheme of albite to jadeite and quartz in anhydrous medium above $P=0.035+0.00265 T$ $\left({ }^{\circ} \mathrm{C}\right) \pm 0.05 \mathrm{GPa}^{7,15,16}$.

The other crystalline by-product along with the hydrated smectite, moganite, is known to be a stable polymorph of quartz under alkaline environment in the $\mathrm{pH}$ range between 9.5 and 10.5 (or $\Delta \mathrm{pH}$ of 2.5-3.5 range) ${ }^{23}$. In fact, the breakdown reaction (1) requires the release of $\mathrm{Na}(\mathrm{OH})$, which is expected to be dissolved in the remaining fluid medium under our experimental conditions and hence not detectable in the observed XRD pattern. Further increase in pressure and temperature above $4.3 \mathrm{GPa}$ and $435^{\circ} \mathrm{C}$, i.e., near $135 \mathrm{~km}$ depth conditions, results in the breakdown of the hydrated $\mathrm{Na}$-smectite as the characteristic $d_{001}$ $\sim 12 \AA$ peak disappears ${ }^{24}$, as below (Fig. 2).

$$
\begin{gathered}
\mathrm{NaAl}_{2}\left(\mathrm{Si}_{3} \mathrm{Al}\right) \mathrm{O}_{10}(\mathrm{OH})_{2} \cdot \mathrm{H}_{2} \mathrm{O} \rightarrow \mathrm{NaAlSi}_{2} \mathrm{O}_{6}+\mathrm{SiO}_{2}+\mathrm{Al}_{2} \mathrm{O}_{3}+2 \mathrm{H}_{2} \mathrm{O} \\
1 \mathrm{~W} \mathrm{Na} \text { - smectite(beidellite) Jadeite Moganite Corundum }
\end{gathered}
$$

Interestingly, when the thermal gradient follows that of warm subduction slab in the presence of water as a PTM, we observed the partial breakdown of albite into jadeite $\left(\mathrm{NaAlSi}_{2} \mathrm{O}_{6}\right)$ and $\alpha$ quartz $\left(\mathrm{SiO}_{2}\right)$ above $2.2 \mathrm{GPa}$ and $375^{\circ} \mathrm{C}$ or ca. $70 \mathrm{~km}$ depth 

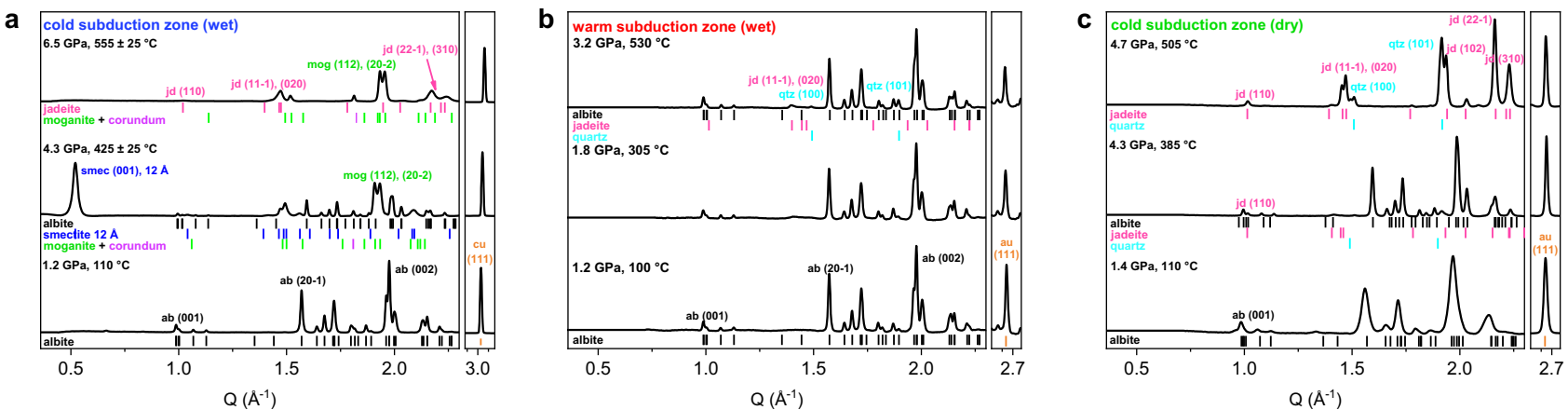

Fig. 2 In situ X-ray diffraction patterns representing the stability of albite under three different PT conditions. a Hydration and dehydration breakdowns from albite under aqueous cold subduction conditions up to $6.5 \mathrm{GPa}$ and $555^{\circ} \mathrm{C}$. The tick marks indicate albite (black, triclinic Cī) ${ }^{45}, \mathrm{Na}$-smectite (blue, monoclinic $\mathrm{C} 2 / \mathrm{m})^{46,47}$, jadeite (pink, monoclinic $\left.\mathrm{C} 2 / \mathrm{c}\right)^{48}$, moganite (green, monoclinic I2/a) ${ }^{49}$, and corundum (purple, rhombohedral R $\overline{3} \mathrm{c}$ ) 50 . The copper and gold peaks were used as pressure scales (orange, cubic $\mathrm{Fm} 3 \mathrm{~m})^{51,52}$. b Albite undergoes partial breakdown into jadeite $\left(\mathrm{NaAlSi}_{2} \mathrm{O}_{6}\right)$ and $\alpha-q u a r t z$ $\left(\mathrm{SiO}_{2}\right)$ without forming smectite under aqueous warm subduction conditions up to $3.2 \mathrm{GPa}$ and $530^{\circ} \mathrm{C}$. c Albite undergoes previously known breakdown into jadeite and $\alpha$-quartz under anhydrous cold subduction conditions up to $4.7 \mathrm{GPa}$ and $505^{\circ} \mathrm{C}$. Phase abbreviations: albite: ab; smectite: smec; moganite: mog; jadeite: jd; and quartz: qtz.

conditions but could not observe the formation of the hydrated Na-smectite from albite up to $3.2 \mathrm{GPa}$ and $530^{\circ} \mathrm{C}$ or ca. $100 \mathrm{~km}$ depth conditions (Figs. 1, 2b, and Supplementary Fig. 3b). When the experiments are repeated under dry conditions along the cold subduction zone, we also observed the previously known breakdown of albite into jadeite and $\alpha$-quartz above $4.3 \mathrm{GPa}$ and $385^{\circ} \mathrm{C}$ or ca. $135 \mathrm{~km}$ depth conditions (Figs. 1, 2c, and Supplementary Fig. 3c $)^{15,25}$. As for the formation of the quartz, it has been known that the compression of the a-quartz would bypass the stability field of coesite under certain non-hydrostatic compression ${ }^{26}$. Overall, our experimental results manifest that the hydration breakdown of albite into smectite and release of $\mathrm{Na}$ $(\mathrm{OH})$ is specific for the hydrous cold subduction environments (Figs. 1, 2a, and Supplementary Fig. 3a) and hence the contemporary global subduction system ${ }^{20}$.

Scanning electron microscopy and FT-IR measurements on the starting and recovered samples. In order to confirm the hydration breakdown reaction of albite into the hydrated smectite and concurrent release of $\mathrm{Na}^{+}$and $(\mathrm{OH})^{-}$into the surrounding fluid medium, scanning electron microscopy (SEM) and FT-IR measurements were performed on the starting and recovered samples. The SEM images show unambiguous transformation in the crystal morphology from albite into the smectite clay in the recoverd sample under wet conditions (Fig. 3). Mid-IR spectra from the recovered sample also reveal new features in absorbance spectrum at $3484 \mathrm{~cm}^{-1}$ and $3587.8 \mathrm{~cm}^{-1}$ (inset in Fig. $3 \mathrm{~b}$ ). The latter vibration is identified as the IR-active stretch mode of $\mathrm{OH}$ in $\mathrm{Na}(\mathrm{OH})^{27}$, while the former broad streching band indicates the presence of interlayer water molecules in the $1 \mathrm{~W} \mathrm{Na-smectite}{ }^{28}$. We thus confirm the reaction (1) where anhydrous albite under hydrous cold subduction conditions breaks down into a hydrated clay mineral, a quartz polymorph, and corundum by releasing $\mathrm{Na}^{+}$and $(\mathrm{OH})^{-}$species to form alkaline fluid environment. Up to our knowledge, this is the first experimental observation of breakdown into a hydrated clay and release of alkaline species from subducting oceanic crustal mineral ${ }^{29}$. Considering the estimated content of albite in basalt, i.e., $~ 16 \%$ in volume, in the subducting oceanic crust, our experimental design of the 1:1 volume mixture of albite and water translates to the water contents of ca. 5 wt. $\% \mathrm{H}_{2} \mathrm{O}$, which is assumed to be the water content in the cold subduction zone $e^{9,30,31}$. Furthermore, the formation of the hydrated Na-smectite from albite is confirmed by XRD and SEM measurements on the quenched samples from ex situ large volume press syntheses at $2.4 \mathrm{GPa}$ and $260^{\circ} \mathrm{C}$ conditions using lower water-to-sample ratios from 50 wt.\% $\mathrm{H}_{2} \mathrm{O}$ down to 6 wt.\% $\mathrm{H}_{2} \mathrm{O}$ (Fig. $3 \mathrm{c}$ and Supplementary Data Fig. 2). Our lowest waterto-albite ratio of 6 wt.\% $\mathrm{H}_{2} \mathrm{O}$ would then translate to the basalt with ca. 0.9 wt. $\% \mathrm{H}_{2} \mathrm{O}$. According to van Keken et al. ${ }^{9}$, the water content of basalt at $90 \mathrm{~km}$ depth in a cold subducting slab, which is the depth of our hydration breakdown of albite, would be maintained to be over 2 wt.\%, while warm subducting slabs would be almost dehydrated by ca. $90 \mathrm{~km}$. Therefore, our experimental conditions would simulate that if hydrous minerals contribute water down to ca. $90 \mathrm{~km}$ depth to make the cold subducting slab wet, the hydration breakdown of albite into smectite would occur.

Ex situ high-pressure and high-temperature studies with a modified Griggs apparatus. In order to complement our experimental findings using a single mineral phase in a DAC, we have expanded our investigation into a macroscopic scale using a natural basalt rock containing ca. 66 vol.\% of feldspars. Two sets of $3 \mathrm{~mm}$ diameter core-drilled samples of a basalt were heated at $250^{\circ} \mathrm{C}$ and $2.5 \mathrm{GPa}$ for $10 \mathrm{~h}$ using a modified Griggs apparatus (Fig. 1). In order to simulate hydrous conditions expected along the cold subduction system, one set was contained with ca. $5.5 \mathrm{wt}$. $\%$ of water in a sealed platinum capsule, while the other was treated without water. The recovered sample from the wet run showed that sample has been severely eroded, compared to the fresh sample from the dry run (Fig. 3). XRD data clearly revealed the presence of $\sim 12.9 \AA$ peak in the sample recovered from the wet run (Supplementary Fig. 4).

\section{Discussion}

The observed sequential breakdowns from albite lead to significant changes in the net crystalline density (see "Methods" and Supplementary Table 1). When albite breaks down into the smectite mixture at ca. $90 \mathrm{~km}$ depth conditions, the net crystalline density increases, i.e., from $2.58(1) \mathrm{g} \mathrm{cm}^{-3}$ to $2.63(1) \mathrm{g} \mathrm{cm}^{-3}$, as the $1 \mathrm{~W}$ Na-smectite, moganite, and corundum form with densities of 1.76 (1) $\mathrm{g} \mathrm{cm}^{-3}, 2.62(1) \mathrm{g} \mathrm{cm}^{-3}$, and $3.90(1) \mathrm{g} \mathrm{cm}^{-3}$, respectively, in the molar ratio shown in the reaction scheme (1). Subsequently upon the breakdown of the $1 \mathrm{~W} \mathrm{Na-smectite} \mathrm{at} \mathrm{ca.} 135 \mathrm{~km}$ depth conditions, the net crystalline density then increases by ca. $11 \%$ 

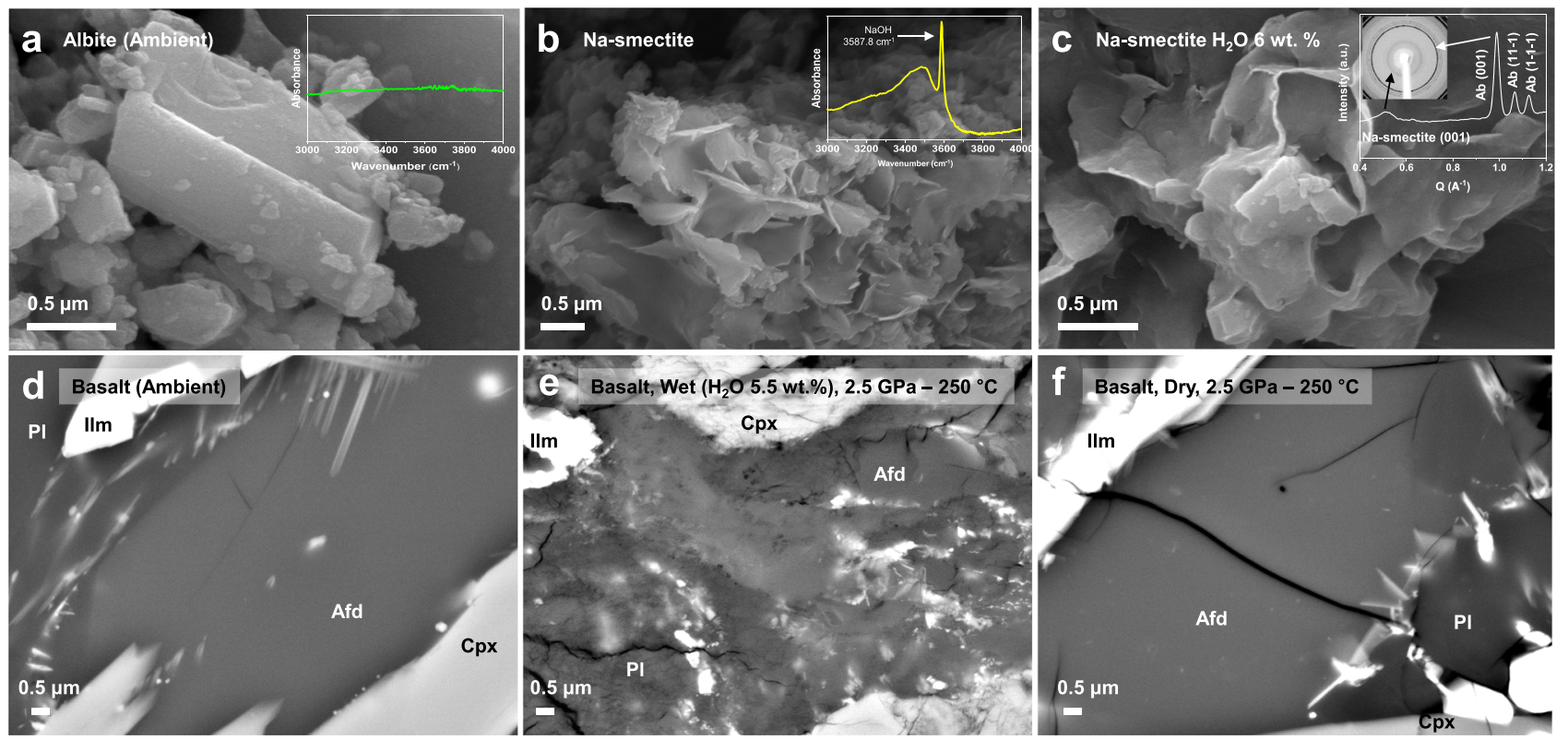

Fig. 3 SEM images of the original albite (basalt) and its recovered products after different PT treatments. Mid-IR spectra from respective samples are shown as inset images. a The original anhydrous albite is characterized by its prismatic crystal habits and featureless IR spectra (upper inset) whereas b the recovered product under 1:1 albite-to-water ratio shows the characteristic clay crystal habits and the IR band (upper inset) by $\mathrm{NaOH}$ at $3587.8 \mathrm{~cm}^{-1}$ (ref. ${ }^{27}$ ). The $\mathrm{O}-\mathrm{H}$ stretching mode of the hydrated Na-smectite is also identified as a broad band at $3484 \mathrm{~cm}^{-1}$. c A representative SEM image and XRD pattern (upper inset) of the recovered product using $6 \mathrm{wt} . \% \mathrm{H}_{2} \mathrm{O}$ from $2.4 \mathrm{GPa}$ and $260^{\circ} \mathrm{C}$ conditions (see Supplementary Fig. 2 for data using different water contents). d A representative SEM image of the original natural basalt (starting material). e A representative SEM image of the recovered basalt sample from $2.5 \mathrm{GPa}$ and $250^{\circ} \mathrm{C}$ under wet condition by $5.5 \mathrm{wt} \% \mathrm{H}_{2} \mathrm{O}$. f A representative SEM image of the recovered basalt sample from $2.5 \mathrm{GPa}$ and $250^{\circ} \mathrm{C}$ under dry condition. Phase abbreviations: alkali-feldspar: Afd; plagioclase: Pl; clinopyroxene: Cpx, augite; and ilmenite: IIm.

from $2.68(1) \mathrm{g} \mathrm{cm}^{-3}$ to $2.98(1) \mathrm{g} \mathrm{cm}^{-3}$. On the other hand, if we assume the starting volume of water is the same as that of albite, the net fluid volume would decrease by ca. $14 \%$, e.g., from $1 \mathrm{~m}^{3}$ to $0.86 \mathrm{~m}^{3}$, upon the formation of the $1 \mathrm{~W} \mathrm{Na}$-smectite at ca. $90 \mathrm{~km}$ depth, and then increase by ca. $8 \%$, e.g., from $0.86 \mathrm{~m}^{3}$ to $0.93 \mathrm{~m}^{3}$, upon the breakdown of the $1 \mathrm{~W} \mathrm{Na-smectite} \mathrm{at} \mathrm{ca.} 135 \mathrm{~km}$ depth (Supplementary Table 1). The increase in the net fluid volume would correspond to ca. $9 \mathrm{wt}$ \% release of water, which is higher than the amount of water released by the dehydration breakdown of hydrated subducting minerals such as phengite and amphibole, i.e., ca. $4.3 \mathrm{wt} . \%$ and $2 \mathrm{wt} . \%$, respectively ${ }^{32}$. When we extend the estimated changes of the net density and fluid volume to subducting basalt composed of $\sim 16$ vol.\% of albite, the degree of changes in the net density is modulated compared to those based on albite alone, i.e., the net density of the basalt is $3.16(1) \mathrm{g} \mathrm{cm}^{-3}$ at ambient condition, increases to $3.17(1) \mathrm{g} \mathrm{cm}^{-3}$ upon the formation of the hydrated smectite at ca. $90 \mathrm{~km}$ depth, and then further increases to $3.22 \mathrm{~g} \mathrm{~cm}^{-3}$ upon the breakdown of the hydrated smectite into jadeite and quartz at ca. $135 \mathrm{~km}$ depth. However, the degree of changes in the net fluid volume is comparable to the changes estimated based on albite alone, i.e., concomitant to the discontinuous changes in the net density of basalt, the net fluid volume decreases by ca. $11.5 \%$ and then increases by ca. $6 \%$. Such concerted and discontinuous changes in the net fluid volume and crystalline density via hydration (reaction 1) and subsequent dehydration (reaction 2) breakdowns would impact the physical properties of the subducting slab itself and hence the earthquake-triggering mechanism in the depth range between ca. 90 and $135 \mathrm{~km}$ along the cold subducting slabs.

Seismic data along the South Mariana trench are in line with our observations that the intermediate-depth earthquakes increase by ca. $93 \%$ as the depth range increases from $70-90 \mathrm{~km}$ to $90-110 \mathrm{~km}$ (International Seismological Centre, ISC Bulletin), which is close to the region of the observed hydration breakdown of albite into a smectite clay. Ikari and Kopf, and Hirono et al. have recently shown that the presence of low-friction clay minerals such as smectite may play an important role in the dynamic weakening processes ${ }^{33,34}$. Based on the friction experiments simulating plate convergence rates of centimeters per year, they discovered unstable slip behavior in clay-dominated faults. The low shear strength of weak clay minerals in clayey fault would favor earthquake rupture accompanying large slip. Our results thus extend such a clay-mediated earthquake generation to deeper depths along subduction zone. At the depth range of $110-130 \mathrm{~km}$, the frequency of earthquake occurrence decreases in comparison to the $90-110 \mathrm{~km}$ region. In the $130-150 \mathrm{~km}$ region, the earthquake frequency increases again by ca. $104 \%$, which is the region where the dehydration breakdown of the smectite clay into jadeite occurs (Fig. 4). This can be well associated with the established dehydration embrittlement theory for intermediatedepth earthquakes ${ }^{35}$. In order to distinguish our new finding of the formation of hydrated clay mineral along cold subduction zone and its association with seismicity increase from dehydration embrittlement, we propose a new term, "hydration faulting (or smectization faulting)" as a possible new mechanism of subduction zone earthquakes. We encourage future studies to test our hypothesized mechanism that the increased seismicity is mainly from this hydration-related dynamic weakening process, and such phenomenon can be found in other subduction zones.

Furthermore, our results help us gain new insights into the geochemical processes occurring along cold subduction zones where fluid is transported deep into the mantle (Fig. 4) 9,36 . The extrapolated $\Delta \mathrm{pH}$ of fluid in equilibrium with subducting basaltic $\mathrm{slab}^{3}$ to the temperature where the hydration breakdown of albite into a smectite clay has been observed is ca. 2.5 , which is within the $\Delta \mathrm{pH}$ range for the concurrent formation of moganite. The 


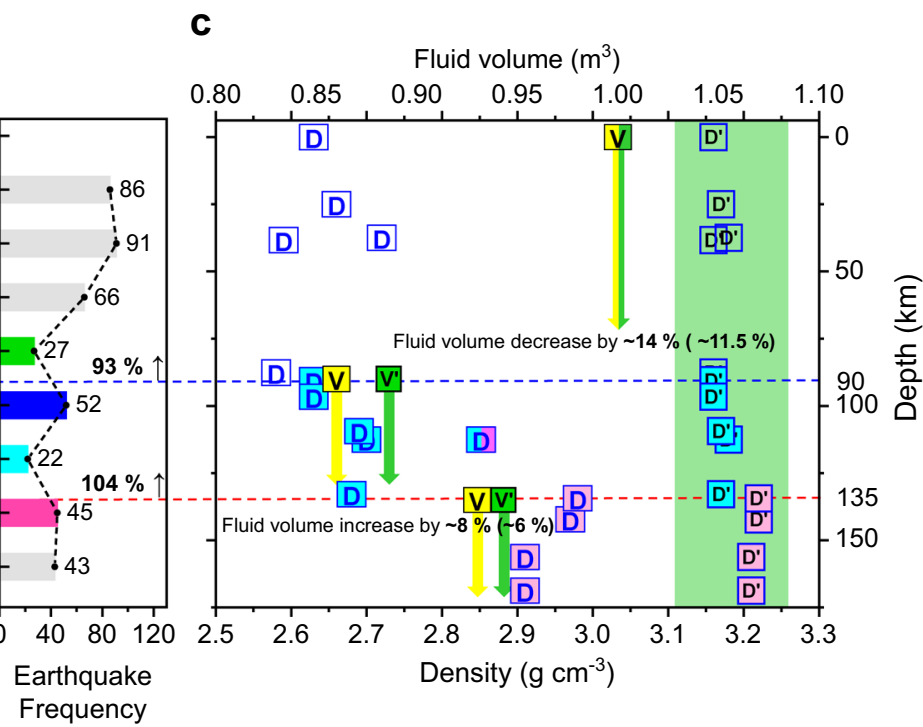

Fig. 4 The breakdown model of albite along the South Mariana trench. a The hydration and dehydration breakdowns of albite occur at ca. $90 \mathrm{~km}$ and 135 $\mathrm{km}$ depths, respectively. $\mathbf{b}$ The frequency of earthquake occurrence along the South Mariana trench over past 5 years (ISC Bulletin, investigation period between Nov. 2014 and Nov. 2019). c Changes in the net crystalline density ( $D$ for albite, $D^{\prime}$ for basalt) and fluid volume ( $V$ for albite, $V$ ' for basalt) in the subducting system are estimated as a function of subducting depth as in $\mathbf{a}$ and $\mathbf{b}$. Green arrow and region highlight the estimated changes based on a basalt system. Phase abbreviations: albite: ab; smectite: smec; moganite: mog; corundum: crn; jadeite: jd; and water: w.

origin of calc-alkaline magma in the overriding mantle wedge might also be related to the breakdown of albite and release of $\mathrm{Na}$ $(\mathrm{OH})$ to the surrounding fluid ${ }^{37}$.

Our results also shed new insights into interpreting anomalies in electrical and seismic properties along cold subduction zones. It has been suspected that the presence of hydrous minerals and/ or increased melt/fluid fractions enhance electrical conductivity and seismic wave attenuation along with the thermal gradient of the subduction zone ${ }^{38}$. The conductivity model by $\mathrm{Ni}$ et al. and Pommier et al. proposes that the addition of ca. $7 \mathrm{wt} . \% \mathrm{H}_{2} \mathrm{O}$ to basalt at $1200{ }^{\circ} \mathrm{C}$ explains the difference in electrical conductivity between North Chile (ca. 0.04-0.1 S m${ }^{-1}$ ) and Mariana (ca. 0.01 $\left.\mathrm{S} \mathrm{m}^{-1}\right)^{38,39}$. It has been known that warm slab, such as North Chile slab, may have released most of its aqueous fluids by ca. $90 \mathrm{~km}$ depth, whereas cold slab, such as Mariana slab, can still hold the fluids beyond $90 \mathrm{~km}$ depth, enriching partial melt accumulation zones with aqueous phases and leading to lower conductivity values ${ }^{39}$. Our observation on albite subjected to such hydrous cold subduction conditions supports these by showing the hydration breakdown of albite into smectite clay near ca. $90 \mathrm{~km}$ depths removing ca. 14 vol.\% of fluid from the region (assuming a 1:1 mixture of albite and water) and then subsequent dehydration breakdown of smectite into jadeite above ca. $135 \mathrm{~km}$ depth releasing ca. 8 vol.\% of fluid into the region.

\footnotetext{
Methods

Sample. The albite sample used in our DAC experiments is from Cheshire county in New Hampshire, USA. Initial elemental characterization was performed using X-ray fluorescence (XRF, M4 Tornado, Bruker Co.) and XRD (MicroMax-007HF, Rigaku Corp.). For XRF, a combination of $25 \mu \mathrm{m}$ diameter X-ray from polycapillary lens and XFlash silicon drift detector was used to measure relative elemental concentrations at several points on a bulky albite crystal in vacuum. The composition of the albite sample was derived to be $\mathrm{Na}_{1.05} \mathrm{~K}_{0.002} \mathrm{Ca}_{0.001} \mathrm{Al}_{1} \mathrm{Si}_{2.98} \mathrm{O}_{8}$. XRD was performed using a combination of $200 \mu \mathrm{m}$ diameter X-ray ( $\mathrm{Mo}-\mathrm{K}_{1}, \lambda=$ $0.709317(1) \AA$ ) and an imaging plate (IP) detector (R-axis IV ${ }^{++}$, Rigaku Corp.) in transmission geometry. The sample-to-detector distance was $150 \mathrm{~mm}$ and the exposure time was $10 \mathrm{~min}$. Sample was contained in a boron capillary with an inner diameter of $0.3 \mathrm{~mm}$ and rotated between 0 to $180^{\circ}$ during measurement for better powder averaging. $\mathrm{LaB}_{6}$ (NIST SRM $660 \mathrm{c}, a=4.15704(8) \AA$ ) standard powder was used to derive the instrumental parameters. IPanalyzer v3.8 program was used to
} calibrate and process the $2 \mathrm{D}$ diffraction images.
Scanning electron microscopy. Field emission scanning electron microscopy (FESEM, JEOL-7800F) was performed on the original albite (ca. $\times 40,000)$ and its recovered products (ca. $\times 20,000)$. Each sample was coated in platinum (Sputter coater 108auto, Cressington Scientific Instruments) and measured for $120 \mathrm{~s}$ in vacuum. The images were measured under LED (lower electron detector) mode at $10 \mathrm{kV}$.

High-pressure and high-temperature synchrotron XRD. In situ high-pressure and -temperature XRD experiments were performed at the 3D beamline at Pohang Accelerator Laboratory (PAL). Monochromatic X-ray with 0.6888(1) $\AA(18 \mathrm{keV})$ in wavelength and $100 \mu \mathrm{m}$ in size was provided using a DCM (double crystal monochromator) of bent $\mathrm{Si}(111)$ and $\mathrm{Si}(311)$ crystals. Angle-dispersive XRD data were measured using an image plate detector (MarXperts Mar345, $3000 \times 3000$ pixels, exposure time of $400 \mathrm{~s}$ ). $\mathrm{CeO}_{2}$ (NIST SRM $674 \mathrm{~b}, a=5.4115(3) \AA$ ) standard powder was used for the instrument calibration. As a pressure vessel, a symmetrictype diamond-anvil cell (SDAC) was used in combination with a membrane-driven pressure control system (GE Pace5000). The culet diameter of the diamond anvil (type I) was $500 \mu \mathrm{m}$. A rhenium gasket was used after indentation to about $100 \mu \mathrm{m}$ in thickness. A sample chamber of $150 \mu \mathrm{m}$ in diameter was made in the gasket using an electric discharge machine (EDM; Holozoic products). Pure water was used as a PTM in the case of aqueous conditions experiments. Simultaneous P-T condition was created by using a set of house-made resistive coil heater (KanthalA1 wire of 26 gauge and $\phi 0.4 \mathrm{~mm}$ with a DC power supply by Sorensen XG 60-14 Ametek Inc.) to surround each diamond anvil ${ }^{40}$. Temperature was monitored using a K-type thermocouple attached to the pavilion of the diamond anvil close to the sample with the maximum uncertainties of $\pm 3^{\circ} \mathrm{C}^{41}$, and the sample pressure was estimated using the equation of state of the Au pressure marker. XRD at each PT step was measured for $400 \mathrm{~s}$ while rocking the DAC by $4^{\circ}$.

Infrared spectroscopy. Synchrotron IR experiments were performed at the beamline 12D at PAL. FT-IR spectra were measured in the mid-IR range $\left(700-7000 \mathrm{~cm}^{-1}\right)$ using a Vertex $80 \mathrm{v}+$ Hyperion 3000 microscope with $\times 15$ objective and a mercury cadmium telluride (MCT) detector (Bruker Co.). Infrared spectra obtained using synchrotron IR beam with an aperture of $50 \times 50 \mu \mathrm{m}^{2}$, and 128 scans were measured in transmission mode while treating the background from the diamond signal using OPUS 7.5 software (Bruker Co.).

Large volume press experiments. Ex situ high-pressure and -temperature syntheses were performed using a QUICKpress apparatus (Depths of the Earth Co.) on a series of samples at various albite-to-water ratios from $50 \mathrm{wt} \%$ down to 6 wt.\% $\mathrm{H}_{2} \mathrm{O}$ using an analytical balance (Precisa XB 220A). Each albite and water mixture was loaded into a $3.4-\mathrm{mm}$ diameter and $12-\mathrm{mm}$ height Teflon capsule. A piston of $10 \mathrm{~mm}$ diameter and a cylindrical graphite heater were used to treat the sample at $2.4 \mathrm{GPa}$ and $260^{\circ} \mathrm{C}$ for $1 \mathrm{~h}$. Each recovered product was identified using FE-SEM and XRD as described above (Fig. $3 \mathrm{c}$ and Supplementary Fig. 2). 
A modified Griggs apparatus experiment and SEM-EDS measurement. The starting material was a natural basalt rock collected from Jeongok in Korea. The sample is massive and fine-grained containing plagioclase ( 56 vol.\%), alkalifeldspar ( $\sim 10$ vol.\%), clinopyroxene (augite) ( $\sim 10$ vol.\%), olivine (forsterite) $(\sim 23$ vol.\%), and ilmenite ( $\sim$ vol.\%). The composition of feldspars was measured using the JEOL JXA-8530F field emission electron probe microanalyzer (FE-EPMA) at the National Center for Inter-university Research Facilities at Seoul National University (SNU), Korea. The measurement conditions included accelerating voltage of $15 \mathrm{kV}$, current of $10 \mathrm{nA}$, and beam size of $10 \times 10 \mu \mathrm{m}^{2}$. The derived chemical formula of feldspars was $\mathrm{K}_{0.02} \mathrm{Na}_{0.36} \mathrm{Ca}_{0.62} \mathrm{Al}_{1.60} \mathrm{Si}_{2.38} \mathrm{O}_{8}$ for plagioclase (labradorite), and $\mathrm{K}_{0.32} \mathrm{Na}_{0.58} \mathrm{Ca}_{0.04} \mathrm{Al}_{0.98} \mathrm{Si}_{2.88} \mathrm{O}_{8}$ for alkali-feldspar (sanidine). Using a modified Griggs apparatus ${ }^{42}$ housed at the Tectonophysics Laboratory at the School of Earth and Environmental Sciences (SEES) at SNU, a core-drilled basalt sample with $3 \mathrm{~mm}$ diameter was pressurized up to $2.5 \mathrm{GPa}$ over $10 \mathrm{~h}$ and then heated up to $250^{\circ} \mathrm{C}$ in $15 \mathrm{~min}$, which was held for $10 \mathrm{~h}$. The experiments were performed at dry and wet $\left(5.5 \mathrm{wt} . \% \mathrm{H}_{2} \mathrm{O}\right)$ conditions. A graphite heater was used, and temperature was monitored using a B-type thermocouple to the maximum uncertainties of $\pm 10^{\circ} \mathrm{C}$. After the P-T run, the sample was quenched to room temperature. Field emission-scanning electron microscopy with energy dispersive spectroscopy (FE-SEM-EDS) measurement was carried out on the recovered core samples using the FE-SEM (JSM 7100F) and the EDS system (Oxford Instruments) at the SEES at SNU. Back-scattered electron images of the recovered samples were also obtained using the same FE-SEM (JSM 7100F), which was operated at an accelerating voltage of $15 \mathrm{kV}$ and a working distance of $10 \mathrm{~mm}$.

\section{Calculation procedures of the "net crystalline density" and "net fluid volume"} Net crystalline density. Density of each phase was calculated using $\rho_{\text {calc }}\left(\mathrm{g} \mathrm{cm}^{-3}\right)=$ $\left(M Z V^{-1}\right) \times(\text { Avogadro's number })^{-1} \cdot V\left(\AA^{3}\right)$ is derived from profile fitting using the GSAS program ${ }^{43,44} . M$ is the molecular weight and $Z$ is the number of the formula unit per unit cell. Net crystalline density accounts the proportions of the composing crystalline phases. Net crystalline density is described here as:

$$
\rho_{\text {Net crystalline density }}=a \rho_{a}+b \rho_{b}+c \rho_{c}+\cdots+z \rho_{z}
$$

where $a, b, c, \ldots$, and $z$ means the proportions of the composing crystalline phases. The calculated density of each phase, $\rho_{a}$, is derived from XRD data.

Net fluid volume. To determine the changes in the net fluid volume after the reaction, the initial volume of albite and water per mole is defined as:

$$
\text { Avogadro's number }\left(\frac{\text { atom }}{\mathrm{mol}}\right) \times \text { unit cell volume of albite }\left(\mathrm{cm}^{3}\right)
$$

The number of the formula unit per unit cell (atom)

Based on the reaction schemes of the hydration (1) and dehydration (2) breakdowns, changes in the net fluid volume are then calculated.

\section{Data availability}

All data generated or analyzed during this study are included with this published article and its Supplementary Information.

Received: 14 August 2020; Accepted: 21 January 2021; Published online: 19 February 2021

\section{References}

1. White, D. A., Roeder, D. H., Nelson, T. H. \& Crowell, J. C. Subduction. Geol. Soc. Am. Bull. 81, 3431-3432 (1970).

2. Stern, R. J. Subduction zones. Rev. Geophys. 40, 3-1-3-38 (2002).

3. Galvez, M. E., Connolly, J. A. \& Manning, C. E. Implications for metal and volatile cycles from the $\mathrm{pH}$ of subduction zone fluids. Nature 539, 420-424 (2016).

4. Stern, R. J. \& Gerya, T. Subduction initiation in nature and models: a review. Tectonophysics 746, 173-198 (2018).

5. Grove, T. L., Till, C. B. \& Krawczynski, M. J. The role of $\mathrm{H}_{2} \mathrm{O}$ in subduction zone magmatism. Annu. Rev. Earth. Planet. Sci. 40, 413-439 (2012).

6. Cervantes, P. \& Wallace, P. J. Role of $\mathrm{H}_{2} \mathrm{O}$ in subduction-zone magmatism: new insights from melt inclusions in high-Mg basalts from central Mexico. Geology 31, 235-238 (2003).

7. Hacker, B. R., Peacock, S. M., Abers, G. A. \& Holloway, S. D. Subduction factory 2 . Are intermediate-depth earthquakes in subducting slabs linked to metamorphic dehydration reactions? J. Geophys. Res. 108, 2030 (2003).

8. Hacker, B. R., Abers, G. A. \& Peacock, S. M. Subduction factory 1. Theoretical mineralogy, densities, seismic wave speeds, and $\mathrm{H}_{2} \mathrm{O}$ contents. J. Geophys. Res. 108, 2029 (2003).

9. van Keken, P. E., Hacker, B. R., Syracuse, E. M. \& Abers, G. A. Subduction factory: 4. Depth-dependent flux of $\mathrm{H}_{2} \mathrm{O}$ from subducting slabs worldwide. $J$. Geophys. Res. 116, B01401 (2011).
10. Tatsumi, Y. \& Kogiso, T. The subduction factory: its role in the evolution of the Earth's crust and mantle. Geol. Soc. Spec. Publ. 219, 55-80 (2003).

11. Cai, C., Wiens, D. A., Shen, W. \& Eimer, M. Water input into the Mariana subduction zone estimated from ocean-bottom seismic data. Nature 563, 389-392 (2018)

12. Borghini, G., Fumagalli, P. \& Rampone, E. The stability of plagioclase in the upper mantle: subsolidus experiments on fertile and depleted lherzolite. $J$. Petrol. 51, 229-254 (2010).

13. Shen, A. H. \& Keppler, H. Direct observation of complete miscibility in the albite- $\mathrm{H}_{2} \mathrm{O}$ system. Nature 385, 710-712 (1997).

14. Bennett, E. N., Jenner, F. E., Millet, M.-A., Cashman, K. V. \& Lissenberg, C. J. Deep roots for mid-ocean-ridge volcanoes revealed by plagioclase-hosted melt inclusions. Nature 572, 235-239 (2019).

15. Birch, A. F. \& LeComte, P. Temperature-pressure plane for albite composition. Am. J. Sci. 258, 209-217 (1960).

16. Holland, T. J. The reaction albite $=$ jadeite + quartz determined experimentally in the range $600-1200^{\circ} \mathrm{C}$. Am. Mineral. 65, 129-134 (1980).

17. Peacock, S. M. Thermal Structure and Metamorphic Evolution of Subducting Slabs. in Inside the Subduction Factory. (ed. Eiler, J.) 7-22 (American Geophysical Union, 2003).

18. van Keken, P. E., Kiefer, B. \& Peacock, S. M. High-resolution models of subduction zones: Implications for mineral dehydration reactions and the transport of water into the deep mantle. Geochem. Geophys. Geosyst. 3, 1-20 (2002).

19. Hacker, B. R. $\mathrm{H}_{2} \mathrm{O}$ subduction beyond arcs. Geochem. Geophys. Geosyst. 9 , Q03001 (2008).

20. Syracuse, E. M., van Keken, P. E. \& Abers, G. A. The global range of subduction zone thermal models. Phys. Earth Planet. Inter. 183, 73-90 (2010).

21. Ferrage, E. Investigation of the interlayer organization of water and ions in smectite from the combined use of diffraction experiments and molecular simulations. A review of methodology, applications, and perspectives. Clays Clay Miner. 64, 348-373 (2016).

22. Meunier, A. Clays Vol. 1, 472 (Springer, 2005).

23. Kayama, M. et al. Discovery of moganite in a lunar meteorite as a trace of $\mathrm{H}_{2} \mathrm{O}$ ice in the Moon's regolith. Sci. Adv. 4, 1-11 (2018).

24. Cama, J., Ganor, J., Ayora, C. \& Lasaga, C. A. Smectite dissolution kinetics at $80^{\circ} \mathrm{C}$ and $\mathrm{pH}$ 8.8. Geochim. Cosmochim. Acta 64, 2701-2717 (2000).

25. Mookherjee, M. et al. Pressure induced elastic softening in framework aluminosilicate-albite $\left(\mathrm{NaAlSi}_{3} \mathrm{O}_{8}\right)$. Sci. Rep. 6, 1-10 (2016).

26. Carl, E.-R. et al. High-pressure phase transitions of $\alpha$-quartz under nonhydrostatic dynamic conditions: A reconnaissance study at PETRA III. Meteorit. Planet. Sci. 52, 1465-1474 (2017).

27. Krobok, M., Johannsen, P. \& Holzapfel, W. Raman and FTIR study of $\mathrm{NaOH}$ and NaOD under pressure. J. Phys. Condens. Matter 4, 8141 (1992).

28. Kloprogge, J. T. Spectroscopic studies of synthetic and natural beidellites: a review. Appl. Clay Sci. 31, 165-179 (2006)

29. Briggs, R., Utting, A. \& Gibson, I. The origin of alkaline magmas in an intraplate setting near a subduction zone: the Ngatutura Basalts, North Island, New Zealand. J. Volcanol. Geotherm. Res. 40, 55-70 (1990).

30. Schmidt, M. W. \& Poli, S. Treatise on Geochemistry (Second Edition): Devolatilization During Subduction Vol. 4, 669-701 (Elsevier, 2013).

31. Zheng, Y., Chen, R., Xu, Z. \& Zhang, S. The transport of water in subduction zones. Sci. China Earth Sci. 59, 651-682 (2016).

32. Faccenda, M. Water in the slab: a trilogy. Tectonophysics 614, 1-30 (2014).

33. Ikari, M. J. \& Kopf, A. J. Seismic potential of weak, near-surface faults revealed at plate tectonic slip rates. Sci. Adv. 3, el701269 (2017)

34. Hirono, T., Tsuda, K. \& Kaneki, S. Role of weak materials in earthquake rupture dynamics. Sci. Rep. 9, 6604 (2019).

35. Jung, H., Green, Ii,H. W. \& Dobrzhinetskaya, L. F. Intermediate-depth earthquake faulting by dehydration embrittlement with negative volume change. Nature 428, 545-549 (2004).

36. Zheng, Y.-F. Subduction zone geochemistry. Geosci. Front. 10, 1223-1254 (2019).

37. McMillan, P. F. Water solubility and speciation models. in Volatiles in magmas. (eds Carroll, M. R. \& Holloway, J. R.) 131-156 (Mineralogical Society of America, 1994).

38. Pommier, A. Geophysical assessment of migration and storage conditions of fluids in subduction zones. Earth Planets Space 66, 38 (2014).

39. Ni, H., Keppler, H. \& Behrens, H. Electrical conductivity of hydrous basaltic melts: implications for partial melting in the upper mantle. Contrib. Mineral. Petrol. 162, 637-650 (2011).

40. Jenei, Z., Cynn, H., Visbeck, K. \& Evans, W. J. High-temperature experiments using a resistively heated high-pressure membrane diamond anvil cell. Rev. Sci. Instrum. 84, 095114 (2013).

41. Méndez, A. S. J. et al. A resistively-heated dynamic diamond anvil cell (RHdDAC) for fast compression $\mathrm{x}$-ray diffraction experiments at high temperatures. Rev. Sci. Instrum. 91, 073906 (2020).

42. Ko, B. \& Jung, H. Crystal preferred orientation of an amphibole experimentally deformed by simple shear. Nat. Commun. 6, 1-10 (2015). 
43. Le Bail, A., Duroy, H. \& Fourquet, J. L. Ab-initio structure determination of $\mathrm{LiSbWO}_{6}$ by X-ray powder diffraction. Mater. Res. Bull. 23, 447-452 (1988).

44. Toby, B. EXPGUI, a graphical user interface for GSAS. J. Appl. Crystallogr. 34, 210-213 (2001).

45. Harlow, G. E. The anorthoclase structures: the effects of temperature and composition. Am. Mineral. 67, 975-996 (1982).

46. Weir, A. H. \& Greene-Kelly, R. Beidellite. Am. Mineral. 47, 137-146 (1962).

47. Gournis, D., Lappas, A., Karakassides, M. A., Többens, D. \& Moukarika, A. A neutron diffraction study of alkali cation migration in montmorillonites. Phys. Chem. Miner. 35, 49-58 (2008).

48. Prewitt, C. \& Burnham, C. W. The crystal structure of jadeite, $\mathrm{NaAlSi}_{2} \mathrm{O}_{6} . A m$. Mineral. 51, 956-975 (1966).

49. Miehe, G. \& Graetsch, H. Crystal structure of moganite: a new structure type for silica. Eur. J. Mineral. 4, 693-706 (1992).

50. Newnham, R. \& De Haan, Y. Refinement of the $a \mathrm{Al}_{2} \mathrm{O}_{3}, \mathrm{Ti}_{2} \mathrm{O}_{3}, \mathrm{~V}_{2} \mathrm{O}_{3}$ and $\mathrm{Cr}_{2} \mathrm{O}_{3}$ structures. Z. Kristallogr. Cryst. Mater. 117, 235-237 (1962).

51. Anderson, O. L., Isaak, D. G. \& Yamamoto, S. Anharmonicity and the equation of state for gold. J. Appl. Phys. 65, 1534-1543 (1989).

52. Wang, Y. et al. Thermal equation of state of copper studied by high P-T synchrotron x-ray diffraction. Appl. Phys. Lett. 94, 071904 (2009).

\section{Acknowledgements}

This work was supported by the Leader Researcher program (NRF-2018R1A3B1052042) of the Korean Ministry of Science, ICT and Planning (MSIP). We also thank the support of the NRF-2016K1A4A3914691, NRF-2019K1A3A7A09033395, and NRF-

2020R1A2C2003765. Experiments using synchrotron radiation were supported by Pohang Accelerator Laboratory (PAL).

\section{Author contributions}

G.H., H.H., and Y.B. contributed equally to the experiments and data analysis with the help from J.C., T.J., and B.C. Y.P. and H.J. contributed to the modified Griggs apparatus experiment. Y.L. designed the research and worked on the manuscript with all authors.

\section{Competing interests}

The authors declare no competing interests.

\section{Additional information}

Supplementary information The online version contains supplementary material available at https://doi.org/10.1038/s41467-021-21419-6.

Correspondence and requests for materials should be addressed to Y.L.

Peer review information Nature Communications thanks Masayuki Nishi and Weisen Shen for their contribution to the peer review of this work. Peer reviewer reports are available.

Reprints and permission information is available at http://www.nature.com/reprints

Publisher's note Springer Nature remains neutral with regard to jurisdictional claims in published maps and institutional affiliations.

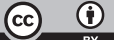

Open Access This article is licensed under a Creative Commons Attribution 4.0 International License, which permits use, sharing, adaptation, distribution and reproduction in any medium or format, as long as you give appropriate credit to the original author(s) and the source, provide a link to the Creative Commons license, and indicate if changes were made. The images or other third party material in this article are included in the article's Creative Commons license, unless indicated otherwise in a credit line to the material. If material is not included in the article's Creative Commons license and your intended use is not permitted by statutory regulation or exceeds the permitted use, you will need to obtain permission directly from the copyright holder. To view a copy of this license, visit http://creativecommons.org/ licenses/by/4.0/.

(C) The Author(s) 2021 